\title{
PSYCHE
}

VOL. XXXVII

TWO NEW ANTS FROM JAVA

By George C. Wheeler and Esther W. Wheeler

University of North Dakota

Phaulomyrma $^{1}$ new genus

o Head flattened, slightly emarginate behind. Eyes protruding, large (diameter about one-third the length of the head), and situated near the anterior border. Clypeus indistinct or large and somewhat convex. Antennæ 13segmented. Thorax compressed. Legs slender; two spurs on the middle and hind tibiæ; metathoracic legs, long, extending beyond the tip of the abdomen. Wings hairy; fore wings large, with one or three reduced veins; the margins fringed with hairs; hind wings much smaller. Hairs abundant especially on the dorsum. Integument smooth or with scattered hairy punctures. Genitalia large and projecting. Sagittæ wide at the base. Subgenital plate bifurcated.

Type: Phaulomyrma javana new species.

This genus is to be distinguished from Leptanilla by the presence of wing veins and the unusually large genitalia.

It is our opinion that Leptanilla tanit Santschi should also be included in this genus.

Phaulomyrma javana new species

o Length-1.2 $\mathrm{mm}$.

Head large, about one-fifth of the entire length, slightly longer than broad, somewhat narrowed behind; the posterior border emarginate.

${ }^{1}$ Phaulos, trifling, paltry + myrmex, ant. 
Eyes large, diameter equal to one-third the length of head, prominent, hairy, hemispherical, situated very far forward. Ocelli oval, almost on the vertex.

Antennæ thirteen-jointed, half as long as the body; flattened; inserted on the anterior margin of the head;

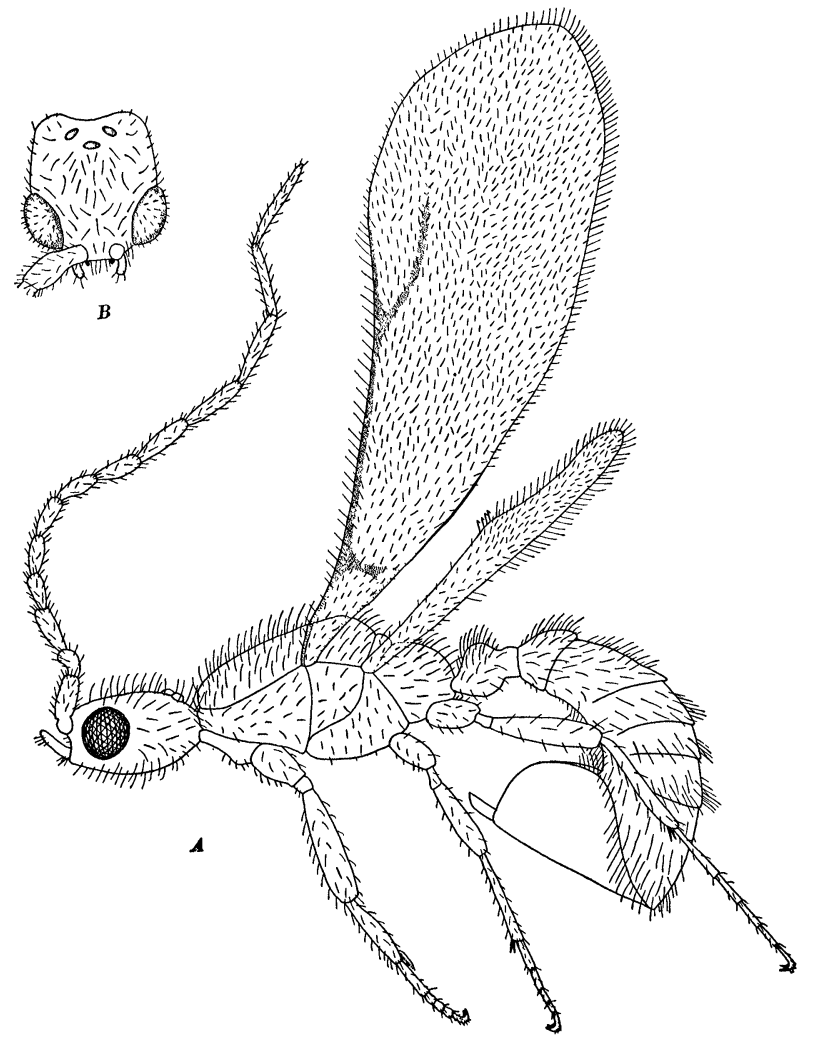

Fig. 1. A. Phaulomyrma javana, lateral view ô. B. Phaulomyrma javana, front view of head.

twice as far apart as the distance from the eyes. First segment thickest, one-third as wide as long; second, onehalf the length of the first, curved and thickened apically; third, as long as the first; fourth to the thirteenth gradu- 
ally lengthening until the thirteenth is one-third longer than the first and one-half as wide.

Mandibles minute, labial palpi prominent, one-jointed. Frontal carinæ very short and indefinite. Clypeus indistinct.

Thorax at its maximum breadth two-thirds the width of the head, compressed into a somewhat cuneiform shape with the thin edge above. Sutures distinct. Pronotum concealed from above. Dorsal profile in lateral view ascending evenly and obliquely, forming an obtuse angle at the middle of the mesoscutellum, depressed at the sutures of the metanotum, which is rounded. Epinotum rounded.

Anterior leg thickened, spur one-half the length of the first tarsal joint; mesothoracic leg shorter and much more slender than the others; meso- and metathoracic tibiæ each with two simple spurs. Hind leg reaching just beyond the tip of the abdomen.

Fore wing three times as long as its greatest width, which is at one-quarter of the length from the apex. Costal and radial veins present, also a cross-vein near the base. Stigma poorly defined. Hind wing very narrow, eight times as long as its greatest width (just beyond the middle) and one-half the length of the fore wing.

Abdomen as wide as the head, one-half the length of the entire insect, and strongly curved so that the sagittæ extend forward to the base of the abdomen. Petiole convex below, attenuated anteriorly; posterior third subcylindrical. Node hemispherical.

Hairs abundant except on the genital capsule which is naked; longer on mouth parts and front, and longest on the dorsum of thorax, apex of node, and dorsal tufts on each abdominal segment; more sparse and half as long ventrally. Eyes with numerous very short hairs. Wings conspicuously hairy; the hairs on the surface short, those fringing the margin much longer, decreasing in length toward the base.

Color ferrugino-testaceous, antennæ lighter. Legs and mouth-parts light yellowish brown. Integument smooth.

Genitalia large and non-retractile. Lamina annularis slightly compressed. Sagittæ widened at the base, the apex extending beyond the stipites; the latter hairy, acuminate, slightly curved, and folded within the lamina annularis. 
Volsellæ thin, plate-like, with broadly rounded free margins. The prongs of the bifurcated subgenital lamina slender, one-fourth as long as the genitalia.

Described from two males from Buitenzorg, Java (III-'07), collected by F. Muir. (Ex. coll. W. M. Wheeler.)

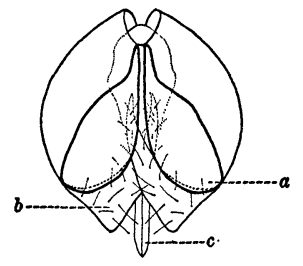

$C$

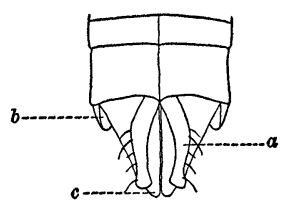

$D$

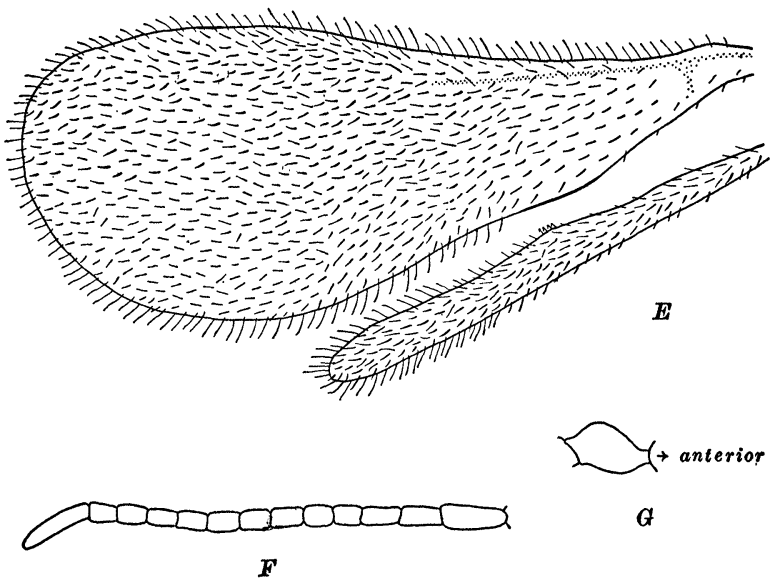

Fig. 2. C. Phaulomyrma javana, ventral view of male genitalia. $a$, Volsellæ; b, Stipites; $c$, Sagittæ. D. Leptanilla santschii, ventral view of male genitalia. E. Leptanilla santschii, wings. F. Leptanilla santschii, antenna. G. Leptanilla santschii, right lateral view of petiole. 
Leptanilla santschii new species

\section{of Length-1.2 mm.}

Head large, about one-sixth the entire length of the body, one and four-fifths times as long as wide, somewhat narrowed behind.

Eyes large, protruding, diameter about one-third the length of the head, situated far forward, hairy, posterior margin slightly emarginate. Median ocellus oval, the others rounded and placed near the vertex.

Antennæ thirteen-jointed, little more than one-half the length of the body. Insertions twice as far apart as the distance from the eye, and situated close to the mouth. First segment almost one-third as wide as long; second and third each, nearly one-half the length of the first; fourth to twelfth, one-third longer than wide; last joint, slightly longer than the first and about one-half as wide.

Mandibles minute. Palpi prominent, single jointed. Frontal carinæ and clypeus indistinct.

Thorax compressed laterally, thinner above than below, depressed at mesoscutellum; measuring one-third the entire length of the body, one-half again as long as deep, fourfifths as wide in dorsal view as the head. Epinotum rounded.

Anterior legs very thick; mesothoracic legs shorter and more slender than the others. Femora thick. Mesothoracic tibia with one spur, metathoracic with two. Hind legs extending beyond the end of the abdomen.

Fore wing two and one-half times as long as its greatest width, which is at one-third the length from the apex. Costal vein and a cross-vein near the base very faintly suggested.

Hind wing ten times as long as its greatest width, which is near the middle, and two-thirds as long as the fore wing.

Abdomen one-third the length of the body and two-thirds the width of the head, rather straight to the sixth segment, which turns downward abruptly, so that the genitalia are at right angles to the rest of the abdomen. Genitalia onesixth the length of the body. Node one and one-half times as long as high. Pedicel very short.

Genitalia conspicuous and probably non-retractile. Sagittæ rather thick, bent forward at the tip, slightly longer 
than the volsellæ which are curved, slender with knob-like apices and several long hairs. Stipites short, broad, and blunt, less than one-half as long as the sagittæ.

Hairs abundant, longer on mouth parts, front, dorsa of the thorax, node, and abdomen; longest on the sixth abdominal segment; shorter on the antennæ; sparser and much shorter ventrally. Eyes with many, very short hairs. Wings conspicuously hairy; the surface hairs short; those fringing the margin twice as long. Genitalia naked, except the volsellæ.

Color ferrugino-testaceous; legs, genitalia, and mouthparts lighter.

Integument smooth.

Described from a single male from Buitenzorg, Java. (Ex coll. W. M. Wheeler.)

In his "Social Life Among the Insects"2 (p. 335) Dr. W. M. Wheeler has suggested that the Tribe Leptanillini would have to be removed from the Dorylinæ and raised to the rank of a subfamily. The senior author ${ }^{3}$, in his study of the larva of Leptanilla revelierei sardoa Emery, has supported this view.

The Leptanillinæ resemble the Dorylinæ in the following characteristics. The frontal carinæ are close together and do not cover the antennal insertions; the petiole consists of two segments in the worker, one in the male and female. A sting is present. The female is wingless; the thoracic sutures are more or less vestigial. In the male the subgenital lamina is usually bifurcate; cerci are absent. The tibiæ have spurs, which are sometimes rudimentary. The larva resembles the known doryline larvæ in the shape of the body, which is elongate, slender, subcylindrical, orthocephalic, and nearly straight, and in the small feebly chitinized mandibles.

In contrast, the following characters of the Leptanillinæ differentiate them from the Dorylinæ. The workers are monomorphic and minute; the maxillary palpi are onejointed; the antennæ are always 12-segmented. The lobed hypopygium of the female extends beyond the pygidium.

${ }^{2}$ New York: Harcourt, Brace \& Co. 1923.

${ }^{3}$ Psyche 35:85-91, 1928. 
In the male the mandibles are very short and have rounded points; the fore wings have few veins or more commonly none at all; the hind wings are veinless; the genitalia are non-retractile. The larva differs in the constriction of the body at the first abdoimnal segment; the absence of hairs on the head; and the presence of long hairs on the abdomen, especially the extremely long pair at the posterior end. But these differences become trivial and insignificant beside three characteristics which not only separate it from doryline larvæ but render it unique among all the known ant larvæ, namely, the plowshare-like structure projecting from ventral side of the prothorax, a "tympanum" on either side of the fourth abdominal segment, and the toothed flaps at either side of the labrum.

We offer the following as a formal definition of the subfamily :

\section{Subfamily Leptanillinæ (W. M. Wheeler) (1910)}

ఈ Hypogæic, monomorphic, minute. Clypeus with a straight border, sometimes with two lobes prolonged between frontal carinæ, which are short. No carinæ on cheeks. Mandibles straight and toothed. Maxillary and labial palpi each with one segment. Eyes absent. Antennæ 12-jointed, inserted farther apart than in the Dorylinæ and having a filiform funiculus. Promesonotal suture marked, other dorsal sutures completely absent. Epinotum unarmed. Tibiæ with a pectinate spur. Claws simple. Petiole of two segments, both nodiform and of almost the same size. Gaster elongate, oval. Pygidium simple.

o Head and thorax like that of the worker. The suture behind the anterior legs fading out dorsally. Wingless. Postpetiole not separated from the following segment by a constriction. Gaster long; cloaca open leaving the sting exposed. Hypopygium longer than the pygidium, with two lateral lobes bent back dorsally.

$\hat{o}$ Head large, more or less rectangular. Clypeus and frontal carinæ somewhat as in worker or indistinct. Mandibles very short, small, rounded, and toothless. Maxillary and labial palpi prominent, one-jointed. Eyes conspicuous, hairy. Antennæ 13-segmented. Scape nearly or quite as long as the next two segments together. Funiculus filiform, 
terminal segment long. Mesothoracic tibiæ with one or two simple spurs, metathoracic with two. Fore wings with few or no veins; stigma never well defined; hind wings veinless. Petiole one-jointed. Genitalia large, non-retractile; subgenital plate bifurcate.

\section{Subfamily Leptanillinæ (W. M. Wheeler $)^{4}$}

\section{Genus Lepantilla Emery ${ }^{5}$}

Leptanilla Emery, 1870, ఛ, Bull. Soc. Ent. Ital. 2:196. Emery, 1904, ఈ, Arch. Zool. 2:107. Santschi, 1907, ô, Rev. Suisse Zool. 15:305.

Leptanilla butteli Forel, 1913, ð Zool. Jahrsb. 36:25. Federated Malay States: Selangor.

Leptanilla doderoi Emery, 1915, ๖, Ann. Mus. Civ. Stor. Nat. Genova $46: 253$, pl. 4, fig. 3, 4 . Emery, 1916, ఛ , Bull. Soc. Ent. Ital. $47: 96$, Sardinia: Teulada.

Leptanilla exigua Santschi, 1908, ô, Ann. Soc. Ent. France $77: 519$, fig. 1, 3. Emery, 1910, ô, Gen. Insect. p. 33. Tunis: Kairouan.

Leptanilla havilandi Forel, 1901, ఫ, Ann. Ent. Soc. Belg. 45 :373. Emery, 1910, $\Varangle$, Gen. Insect. p. 33. Singapore.

Leptanilla minuscula Santschi, 1907, ô, Rev. Suisse Zool. 15 :309, fig. 3. Santschi, 1908, ô, Ann. Soc. Ent. France 77 :520, fig. 2. Emery, 1910, ô, Gen. Insect. p. 33. Tunis : Kairouan.

Leptanilla nana ${ }^{6}$ Santschi, 1915, $\Varangle$, Bull. Soc. Hist. Nat. Afr. Nord. (7me année) 6:55-57, fig. 2. Tunis : Kairouan.

${ }^{4}$ We have not included here the Genus Leptanilloides Mann (Psyche 30:13-14, 1923), because the sexual forms are unknown. To quote Mann (p. 15) -

"In general habitus this [Leptanilloides] is very similar to Leptanilla, but the structure of the head associates it more closely with Eciton, from which it is distinct in the form of the frontal lamellæ, the form of the gaster and in not being polymorphic."

${ }^{5}$ Leptanilla nordenskioldi Holmgren (Zool. Anzeiger 33:347) is an Eciton (Acamatus) according to Emery (Gen. Insect. p. 25, 1910).

${ }^{\circ}$ Santschi says in this paper, "Le $\hat{o}$ du Lep. minuscula Sant. dont la tête est également très allongée, provient des mêmes terrains ot pourrait bien être celui du L. nana." 
Leptanilla santschii, new species. Java: Buitenzorg.

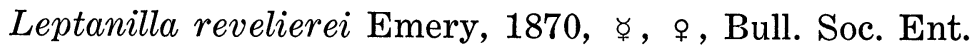
Ital. 2:196, pl. 2, fig. 2, 7. Emery, 1876, ఛ, ᄋ, Stettin, Ent. Zeitg. 37:74. Ern. André, 1882, ఛ̧, ণ, Spec. Hym. Eur. $2: 269$, pl. 16, fig. 4, pl. 17, fig. 1. Dalla Torre, 1893, $\nvdash$, , Cat. Hym. p. 72. Emery, 1904, $\circ$, Arch. Zool. $2: 108$, fig. 1-4. Emery, 1910, ৮,, , Gen. Insect. p. 33, fig. 8. Emery, 1916, ৮,, , Bull. Soc. Ent. Ital. $47: 96$, fig. 8, 9. Corsica: Corte. Sardinia.

Leptanilla revelierei var. bimaculata Emery, 1899, ৮, Bull. Soc. Ent. France p. 20, fig. Emery, 1910, $\Varangle$, Gen. Insect. p. 33. Emery 1916, $\triangleleft$, Bull. Soc. Ent. Ital. 47:96. Corsica.

Leptanilla revelierei subsp. chobauti Emery, 1899, ৮, Bull. Soc. Ent. France, p. 20. Morocco: Tangier.

Leptanilla revelierei subsp. sardoa Emery, 1916, ৮, Bull. Soc. Ent. Ital. 47:97. G. Wheeler, 1928, larva, Psyche 35: 85-87, fig. Sardinia: Carloforte.

Leptanilla tenuis Santschi, 1907, ô, Rev. Suisse Zool. 15 :307, fig. 1. Emery, 1910, ô, Gen. Insect. p. 33. Tunis : Kairouan.

Leptanilla theryi Forel, 1903, ৮, Ann. Soc. Ent. Belg.

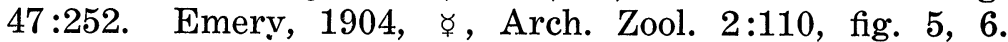
Emery, 1910, $\Varangle$, Gen. Insect. p. 33, pl. fig. 8. Santschi, 1915, \&, Bull. Soc. Hist. Nat. Afr. Nord 6:57-58, fig. 3. Eastern Algeria. Tunis: Sousse.

Leptanilla vaucheri Emery, 1899, ఈ, Bull. Soc. Ent. France, p. 19, fig. Emery, 1910, $\Varangle$, Gen. Insect. p. 33. Morocco: Tangier.

\section{Genus Phaulomyrma new genus}

Phaulomyrma javana, new species. Java: Buitenzorg.

Phaulomyrma tanit Santschi (= Leptanilla tanit Santschi), 1907, ô, Rev. Suisse Zool. 15:310, fig. 2. Emery, 1910, ô, Gen. Insect. p. 33. Tunis: Kairouan. 

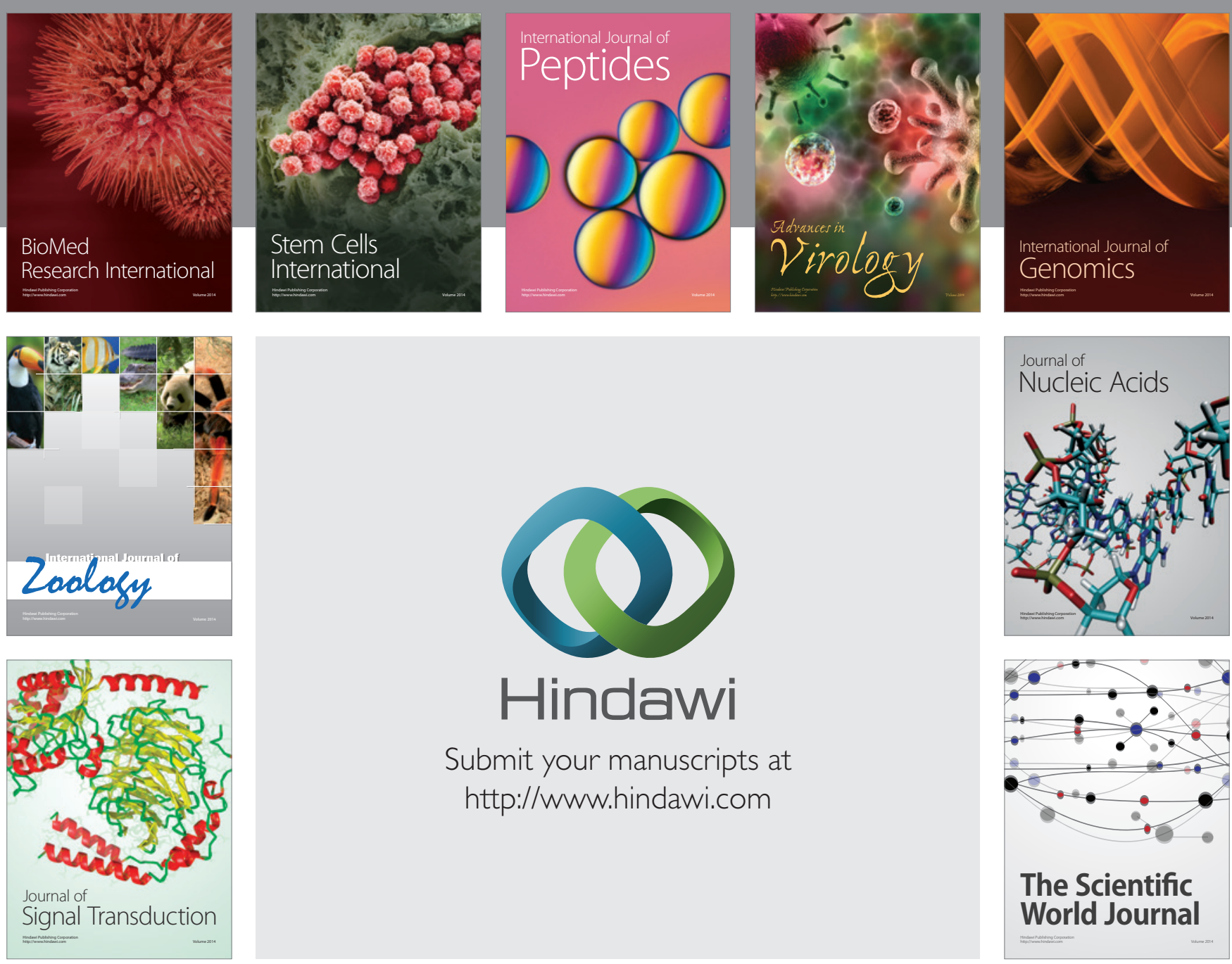

Submit your manuscripts at

http://www.hindawi.com
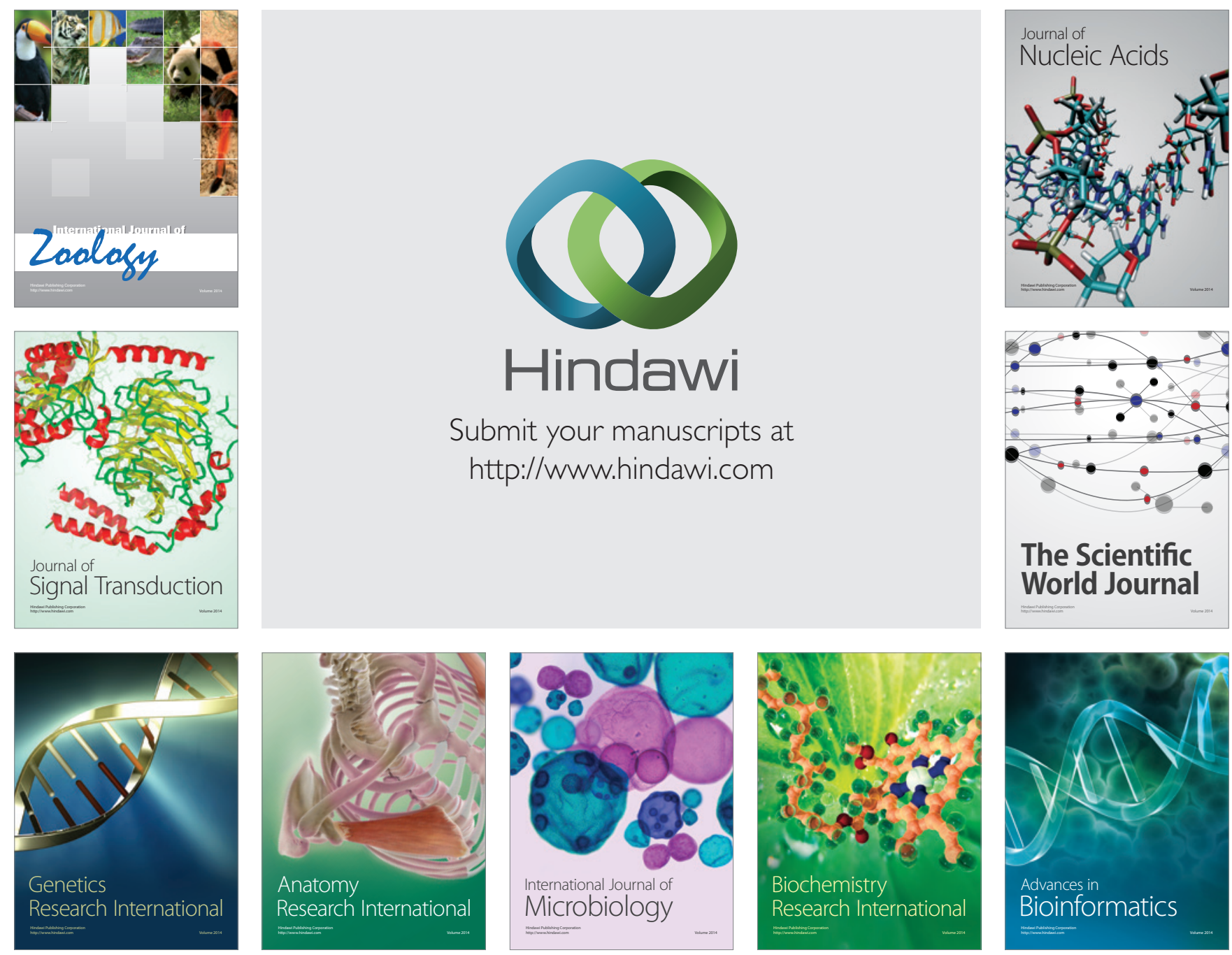

The Scientific World Journal
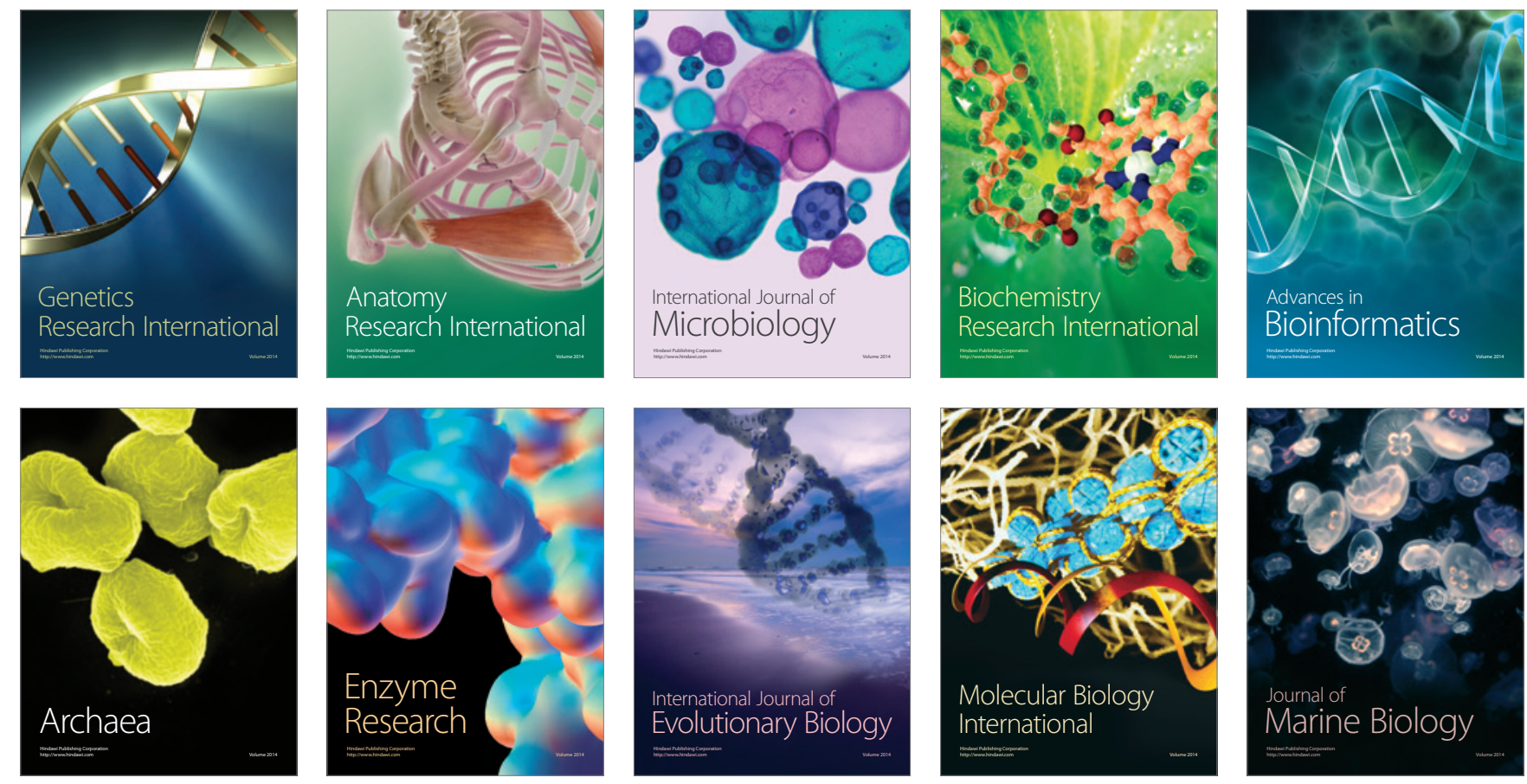